\title{
PERT/MANPOWER問題の効率的最適解法の開発 \\ Development of Algorithm for Obtaining Optimal Solution of PERT/MANPOWER Problem Effectively
}

\author{
立命館大学 \\ 立命館大学 \\ 立命館大学大学院 \\ 春名 攻* \\ 滑川 達** \\ ○伊藤壮央***
}

by Mamoru HARUNA*, Susumu NAMERIKAWA**, Takeo ITO***

\begin{abstract}
本研究においては、PERT/MANPOWER 問題を含む大規模工程ネットワークへの工事用資源の 配分問題の最適解を効率的に導出することができる解法アルゴリスムの開発を行った。本研究で は、これまで PERT/MANPOWER 問題、さらには最適投入量決定問題も内含した工事用資源の 配分問題に対して、既存の PERT 系手法とは異なる観点から各問題を定式化し、最適解が理論的 に確実に求められる方法を明らかにしてきた。ここでは、以上のような理論的成果から得られる 最適性の保証を保持しながら、DP の計算過程に新たな処理を追加することにより、計算量のる削 減を図り、実際レベルの大規模計算にも耐え得る最適解法を開発した。そして、この解法を大規 模工程ネットワークへ適用することにより、操作性の向上を実際に確認した。
\end{abstract}

【キーワード】工程言十画手法、PERT/MANPOWER開題、計算量削減

\section{1. はじめに}

建設プロジェクト施工計画の中核的業務として 位置づけられる工程計画への PERT 系ネットワー ク手法の適用においては、次のような課題が存在 しているものと考えられる。まず、PERT 系ネッ トワーク手法の理論的特徴からみた課題として、

「任意の時間断面での状態を計画変数として取り 扱うことが出来ない」ということが挙げられる。 また、施工計画レベルにおける工程計画での本質 的な検討問題である工事用資源の運用計画という 観点からの課題として、実用面での要請から最適 性の保証のない妥当解しか求めることの出来ない 手法しか存在していないことが挙げられる。

本研究ではこれまでに、以上のような課題を解 決することを目的として、工程ネットワークにお ける「特定の条件を満たすことにより同時実施可 能な作業集合として求められるカットの理論的特 性」に関する分析を行い、工事施工における各作 業の実施過程を PERT 系ネットワーク手法とは異 なる方法により「異なるカットの時間的配列」と して表現できることを明らかにしている。さらに、 本研究では、このような理論的発見を基礎として、

\footnotetext{
*理工学部環境システム工学科 077-561-2736

**理工学研究機構

***大学院理工学研究科

$077-561-2736$

$077-561-2736$
}

すべての種類の工事用資源に対し各時間に投入可 能な工事用資源の量的制約が与えられている場合 に、最短工期となる実行可能な資源配分計画も含 めた作業スケジュールを求める、いわゆる PERT/MANPOWER 問題検討のための工程計画モ デルの開発をめざした。そこでは、理論的な最適 性が保証される形で、問題を後述するカットネッ トワーク上での作業実施パターンを変数とする資 源配分モデルとして従来とは異なる形で定式化し た。そして、解法としては DP を適用することに よって、最適解が確実に求められることを明らか にしてきた。また、同様の方法に用いれば、工事 用資源の最適投入量の決定も含めた資源配分問題 についても最適解を求めることができることを示 してきた。

本稿においては、以上のような理論的成果をべ 一スとして、大規模工程ネットワークを対象とし たコンピュータによる大規模数值演算の実施を可 能とするプログラミングモデルの開発をめざして 構築した効率的解法アルゴリズムの内容を示すこ ととする。そこでは、まず計算量削減を目的とし て、DP を用いた最適経路の探索過程に、ブラン チ\&バウンド法で用いられる下界值と同様の概念 を導入した新たな処理の追加を試みている。さら に、本研究では、これまでの解法の前提となって いたすべてのカットの抽出とカットネットワーク の作成に多くの計算時間を要することを指摘する 
とともに、この課題に対し「一つの工程ネットワ 一クに対して、一対一の写像関係を有するただ一 つのカットネットワークが存在する」という理論 的保証のもと、上述のように変更を加えた DP 計 算を進ていく過程において必要となるカットのみ を生成していく方法を新たに導入した。

\section{PERT/MANPOWER問題の定 式化一これまでの研究成果の整理一}

ここでは、本研究がこれまで行ってきた研究成 果を PERT/MANPOWER 問題の最適解法に関す る開発研究を例として示す。このような成果は、 今回開発する新たな解法アルゴリズムのベースと なった理論であり、本研究との関連性が大変深い 内容であるため、ここで改めて取りまとめること とした。

（1）カット間順序関係構造の存在とカットネ ットワークの構成

本研究では、まずアローダイアグラム型の工程 ネットワークを始点ノードを含む結合点集合と終 点ノードを含む結合点集合とに二分する作業集合 のうち順方向の作業のみから構成される作業集合 を取り出し、これをここで取り上げる「カット」 と定義した。さらに、これらカット間の順序関係 を各カットに含まれる作業の順序関係にもとづい て求めた結果、工事施工における各作業の実施過 程を PERT 系ネットワーク手法とは異なる方法に よって「異なるカットの時間的配列」として表現 できることを明らかにした。すなわち、工程ネッ トワークに表されている作業間順序関係と等価な 関係が、図ー1に示したような特定のカット集合

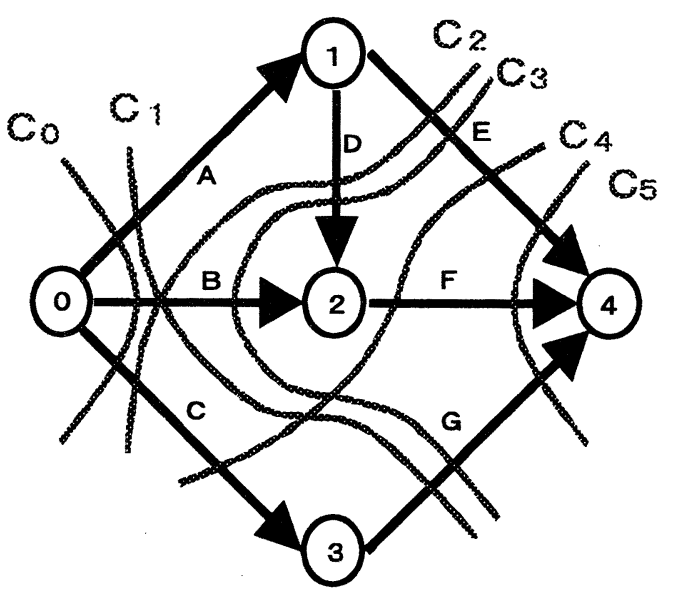

図一 1 カット集合
の中に存在する順序関係として求められることを 理論的に発見した。

そして、このカット間順序関係構造を反映させ た新たなネットワークが図ー2のように、工程ネ ットワークと等価な順序関係構造としてトポロジ カルに求められ、これをカットネットワークとよ ぶとともに、このカットネットワークの一つの経 路が、工事プロジェクトの一つの実施過程を表現 していることを理論的に明らかにしている。
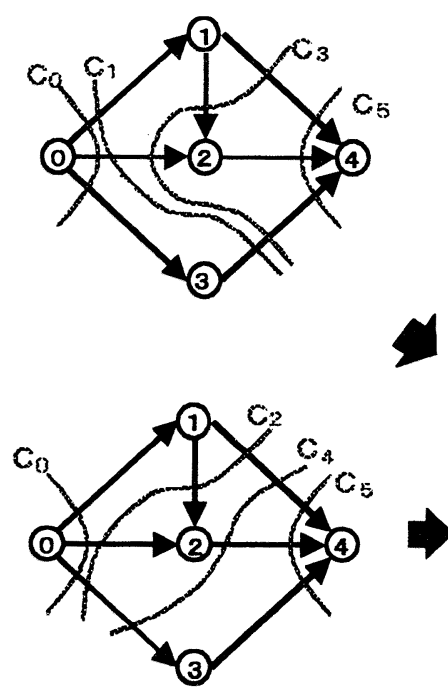

図-2
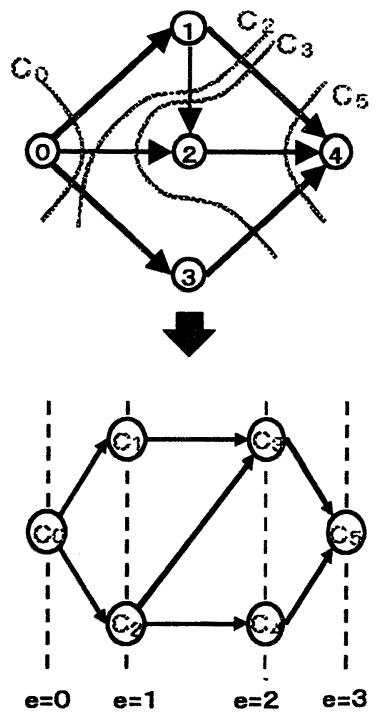

カットネットワーク
（2）カットネットワーク上での資源配分問題 への変換による問題の定式化

本研究では、以上の理論的成果をべースとして、 PERT/MANPOWER 問題を作業間順序関係構造が 写像されているカットネットワーク上での最適経 路選択と、その経路上における作業実施パターン の配分問題として定式化した。なお、この定式化 の段階においては、始点から終点の方向に向かっ て、アクティビティの矢印の方向に辿って順方向 に結ぶすべての相互独立なルートの実施日数を計 画変数として導入するとともに、カットネットワ 一クには図ー2のようにイニシャルレベルを設定 している。

いま、工事の実施状態をカットとそこでの各ル 一トの実施日数で表わすこととすれば、

$$
R_{e}=\left(r_{e}^{1}, r_{e}^{2}, \cdots, r_{e}^{m}\right)
$$

$r_{e}^{\kappa}$ : カットネットワークに設定した任意のレベ ルeおけるルート $\mathrm{k}$ の実施日数

のような $\mathrm{m}$ 次元ベクトルを問題定式化における計 
画変数として設定することができる。

つづいて、決定関数を、上述した各ルートの実 施日数パターンを変数にもつ任意のカット区間の 時間長として設定すれば、以下のような関数

$$
\begin{aligned}
& g_{e}\left(R_{e}\right)=g_{e}\left(r_{e}^{1}, r_{e}^{2}, \cdots, r_{e}^{m}\right) \\
& \quad r_{1}^{k}, r_{2}^{k}, \cdots, r_{n}^{k} \geq 0 \quad(k=1,2, \cdots, m)
\end{aligned}
$$

で表わすことができる。このとき、 PERT/MANPOWER 問題の定式化は、カットネッ トワークにおける各レベルでの決定関数値の総和 の最小化として求められる。すなわち、 PERT/MANPOWER 問題は、

minimize

$$
\mathrm{f}_{\mathrm{n}}\left(r^{1}, r^{2}, \cdots, r^{m}\right)=\sum_{e=1}^{n} g_{e}\left(r_{e}^{1}, r_{e}^{2}, \cdots, r_{e}^{m}\right)
$$

subject to

$$
\sum_{e=1}^{n} r_{e}^{k}=r^{k} \quad(k=1,2, \cdots, m)
$$

のようなカットネットワークにおける最適資源配 分問題として定式化できることがわかる。さらに、 上式定式化における問題の分解が、フィードバッ ク構造をもたないカットネットワークにもとづい て行われているので、DP の基本原理である最適 性の原理が適用でき、次のように変形することが できる。すなわち、

$$
f_{0}(0,0, \cdots, 0)=0
$$

$$
f_{t}\left(r_{t}^{1}, r_{t}^{2}, \cdots, r_{t}^{m}\right)
$$$$
=\min _{\substack{0, r_{t}^{\prime} s r_{t}^{k} \\(s, t) \in C_{N L}}}\left\{g_{s t}\left(r_{s t}^{1}, r_{s t}^{2}, \cdots, r_{s t}^{m}\right)\right.
$$

$$
\begin{gathered}
\left.+f_{s}\left(r_{t}^{1}-r_{s t}^{1}, r_{t}^{2}-r_{s t}^{2}, \cdots, r_{t}^{m}-r_{s t}^{m}\right)\right\} \\
(t=1,2, \cdots, c)
\end{gathered}
$$

$s, t$; カット番号

$r_{t}^{k}$; カット $t$ の直前までに配分されたルート $k$ の実施日数

$r_{s t}^{k}$; カットネットワークのリンク $(s, t)$ に配分す るルート $\boldsymbol{k}$ の実施日数

$C N L$; カットネットワークのリンク集合
のような、繰り返し関数方程式として定式化する ことができ、DP を用いた解法によって最適解の 導出が理論的に保証されることとなる。

また、計画変数を各作業の実施日数としてもま ったく等価な繰り返しの関数方程式が得られる。

$$
f_{0}(0,0, \cdots, 0)=0
$$

$$
\begin{aligned}
& f_{t}\left(d_{t}^{1}, d_{t}^{2}, \cdots, d_{t}^{M}\right)
\end{aligned}
$$

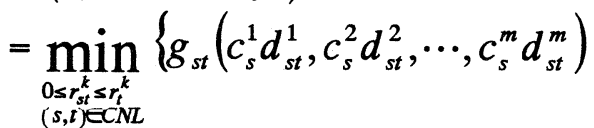

$$
\begin{aligned}
& \left.+f_{s}\left(d_{t}^{1}-d_{s t}^{1}, d_{t}^{2}-d_{s t}^{2}, \cdots, d_{t}^{m}-d_{s t}^{m}\right)\right\} \\
& (t=1,2, \cdots, c)
\end{aligned}
$$

$d_{t}^{i}$; カット $t$ の直前までに配分された作業 $i$ の実

\section{施日数}

$d_{s t}^{i}$; カットネットワークのリンク $(s, t)$ に配分す る作業 $i$ の実施日数

$c_{s}^{1}$; 作業 $i$ がカット $s$ に含まれていれば 1、そう

でなければ 0 となるカット行列の構成要素

ここで、上述した定式化の決定関数値を求める 方法としては以下のようである。まず、本研究が 取り上げた特定のカットは、同時実施が可能な作 業集合として求められているので、任意のカット に含まれる作業間に順序関係は存在しない。した がって、ここでの問題は並列ネットワークを対象 とした作業害施パターンの配分問題を解くことと 等価な問題となる。本研究では、このような並列 ネットワークを対象としたとき、作業実施パター ンの配分問題は、線形計画の問題として定式化す ることとができることを示した。さらに、カット に含まれる作業の数が多く、あらかじめすべての パターンを求めることが困難となる場合には、こ の問題を Cutting一Stock 問題として、列生成法を 用いた解法を採用することにより、各カットへの 作業実施パターンの配分が可能となることを明ら かにしてきた。なお、この詳細な内容については 参考文献 1 ）を参照願いたい。

\section{3. 数値計算のための効率的解法アルゴリ スムの開発}

ここでは、前述の PERT/MANPOWER 問題の 
最適解法における DP 計算過程に、以下のような 新たな処理を導入して、計算量の削減を図るこ とにより、より効率的な解法の開発をめざした。

\section{（1）妥当解を活用した計算量の削減}

ここでは、より一層の計算量削減をめざして、 山崩し法で求められる妥当解を活用した以下の ような処理過程を導入する。すなわち、まず山 崩し法を適用して妥当解としての工期を算出し ておく。そして、カットネットワーク上での最 適経路探索としての DP 計算過程の中で求められ ていく、あるカットまでの作業実施状態に対し て、その段階までにまだ実施されていない延べ の工事用資源量を図一3に示すような各作業へ配 分を考えない理想状態で配分する。そのときの 工期が、先に山崩し法で求めた工期以上であれ ば、以降のスケジュール計算を進めたとしても、 既に算出されている妥当解より優れた解が求め られる可能性がまったくないことが明らかなの で、カットネットワークにおけるこの経路のこ れ以降の探索を終了する。このような処理を DP 計算課程の中に加えることにより、一定レベル （ここでは山崩し法による妥当解）以上の検討 に值し得る意味ある経路の探索を効率的に実施 することができ、より一層の計算量の削減が期 待できる。

なお、カット $t$ における以降の探索の判断過程 を、以下にアルゴリズム化しておく。

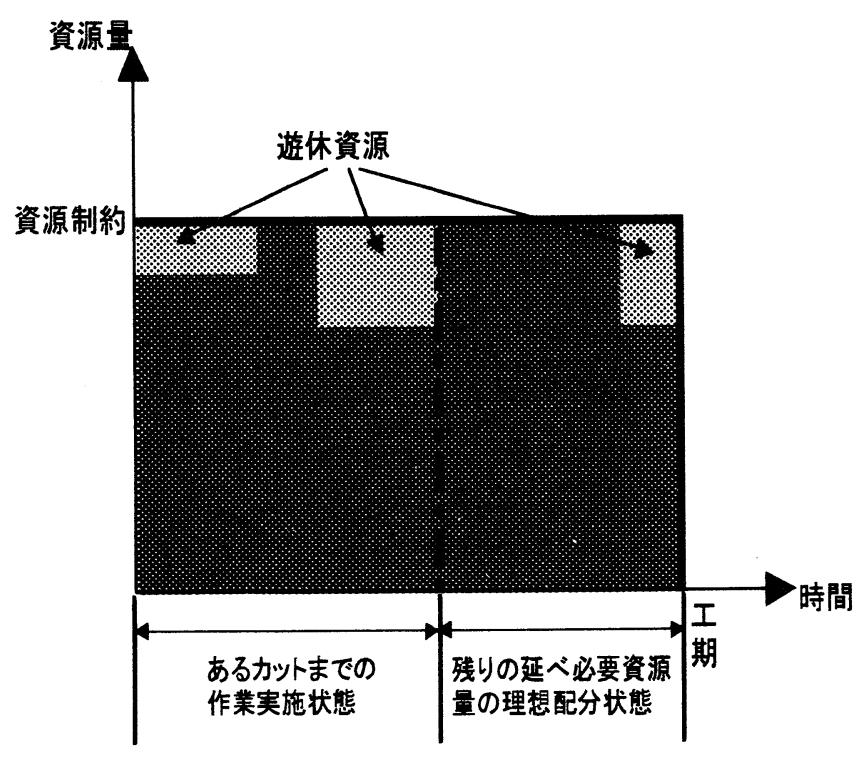

図ー3 あるカットレベルまでに実施されて いない延べ工事用資源量の理想配分の考え方
ステップ 1. 山崩し法を用いたスケジュール計算

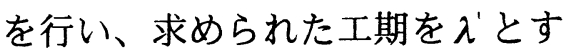
る。

ステップ 2 . いま、DP 計算の途中で求められた カット $t$ までの日数を

$$
f_{t}\left(d_{1}^{t}, d_{2}^{t}, \cdots, d_{n}^{t}\right)=D^{t}
$$

で表し、まだ実施していない延べ の必要資源量 $Z W$ ，を

$$
Z W_{l}=\sum_{i=1}^{M} w_{i l} \cdot\left(d_{i}-d_{i}^{t}\right)
$$

として求める。

ステップ 3 . 作業への配分を考えない理想状態に おける必要日数 ZD を

$$
Z D=\max _{l}\left\{\frac{Z W_{l}}{W_{l}}+\theta_{l}\right\}
$$

として求める。ここで、 $\frac{Z W_{l}}{W_{l}}$ は整 数であり、 $\theta_{l}$ は $\frac{Z W_{l}}{W_{l}}$ の余りが0の とき0、そうでなければ 1 とする。 ステップ $4 . \lambda^{\prime \prime}=D^{t}+Z D$ を計算する。もし、 $\lambda>\lambda$ ならばカット $t$ 以降の計算を 終了する。

（2）カット生成過程の導入

本研究がこれまでに開発してきた最適解法に おいては、まずすべてのカットを抽出し、それ らすべてのカットを要素としたカットネットワ 一クを構成した上で、このカットネットワーク 上での DP 計算を行う方法を採っていた。しかし、 このような方法では、工程ネットワークの規模 が大きくなるにつれ、カットネットワーク作成 までの計算時間が長くなるケースが多々見受け られ、モデルの操作性を低いものとしていた。 本研究が行った計算例では、60 程度の作業数で もカットの数が 1000 を超えるようなネットワー ク構造が存在し、その計算時間が 100 時間を超 えてしまうようなケースも確認している。また、 先に改変したカットネットワークの最適経路探 索では、その計算過程の途中で最適経路とはな り得ない経路が逐次排除されていくが、このよ うな経路の延長上に存在するカットは、結果的 
に使用されることはなく、数値計算の効率性と いう観点からは、抽出を必要としない無䭾な力 ットが多々存在していることが、これまで実施 した適用計算の結果からも明らかになっている。

本研究では、以上のようなモデルの操作性に 関する課題を解決するため、次のようにアプロ 一チした。すなわち、本研究が行ってきたカッ トのトポロジカルな理論的特性分析より、カッ トネットワークが、もとの工程ネットワークと 一対一の対応関係として確実に求められること が理論的に保証されるため、ここでは、すべて のカットを要素とするカットネットワークを暗 に対象としつつ、計算過程の中で必要となる力 ットのみを逐次生成していくこととした。

具体的には、カットネットワークの経路探索 のための DP 計算において探索が 1 レベル進むこ とは、図ー4 に示すように、ある作業が終了しそ

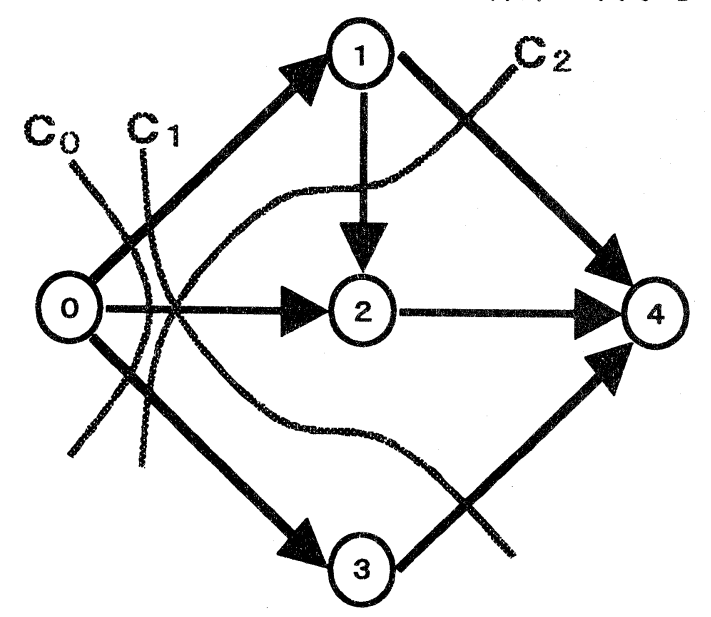

図ー4 カットの進行状態

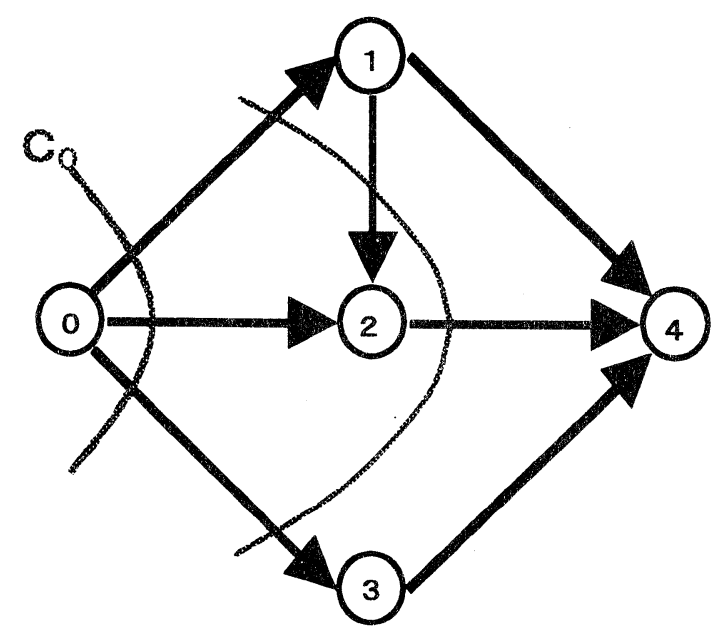

図ー5本研究が定義した「特定のカッ ト」の条件を満足しない進行状態
の作業に対して直接的な後続関係をもつ作業が 開始可能な状態になることと等価である。そし て、このような状態の変化は、現在検討してい たカットが工程ネットワークにおけるノードを 一つ超えて次のカットに変化した状態と考える ことができる。但し、図ー5 のようなカットの進 行状態は、本研究が定義した「特定のカット」 の条件を満足しないため排除しなければならな い。そこで、ここでは DP 計算課程の中で必要と なる特定の条件を満たした意味あるカットのみ を次のように逐次生成していくこととした。

すなわち、まず DP 計算において現在検討して いたカットに含まれている作業群の終点ノード をすべて抽出する。つづいて、それら各ノード が現在検討していたカットに含まれない作業の 終点ノードとなっていないかを調べる。もし、 現在検討していたカットに含まれない作業の終 点ノードとなっている場合には、このノードを 超えるカットの変化は考えない。逆に、このノ 一ドを終点とする作業群すべてが、現在検討し ていたカットに含まれている場合には、さらに、 このカットを始点ノードとする作業をすべて抽 出し、これらの作業と現在検討していたカット に含まれかつこのノードを終点ノードとする作 業を入れ替えることにより、新たなカットを生 成する。このような好理を現在検討していたカ ットに含まれている作業群の終点ノードすべて に加えることにより、現在検討していたカット に後続するすべてカットを生成することができ る。なお、このような処理は以下のように定義 される接続行列を利用することにより、容易に 行うことができる。

$<$ 接続行列 $\left(\delta_{i j}\right)>$

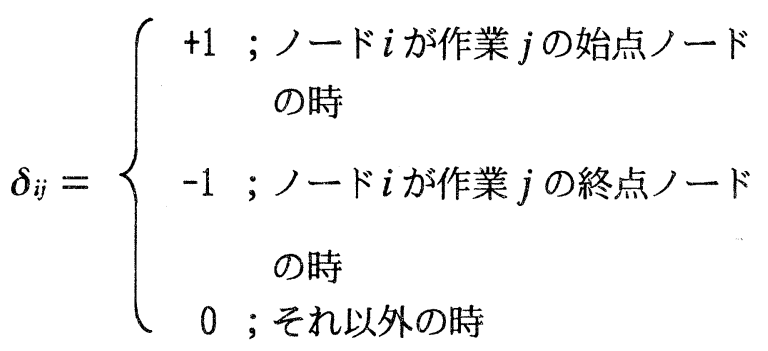

なお、DP 計算がカット $s$ まで行われていると き、後続するカット群を生成するアルゴリズム は以下のようである

ステップ 1. $C_{i}^{s}=1$ かつ $\delta_{v i}=-1$ となる工程ネ 


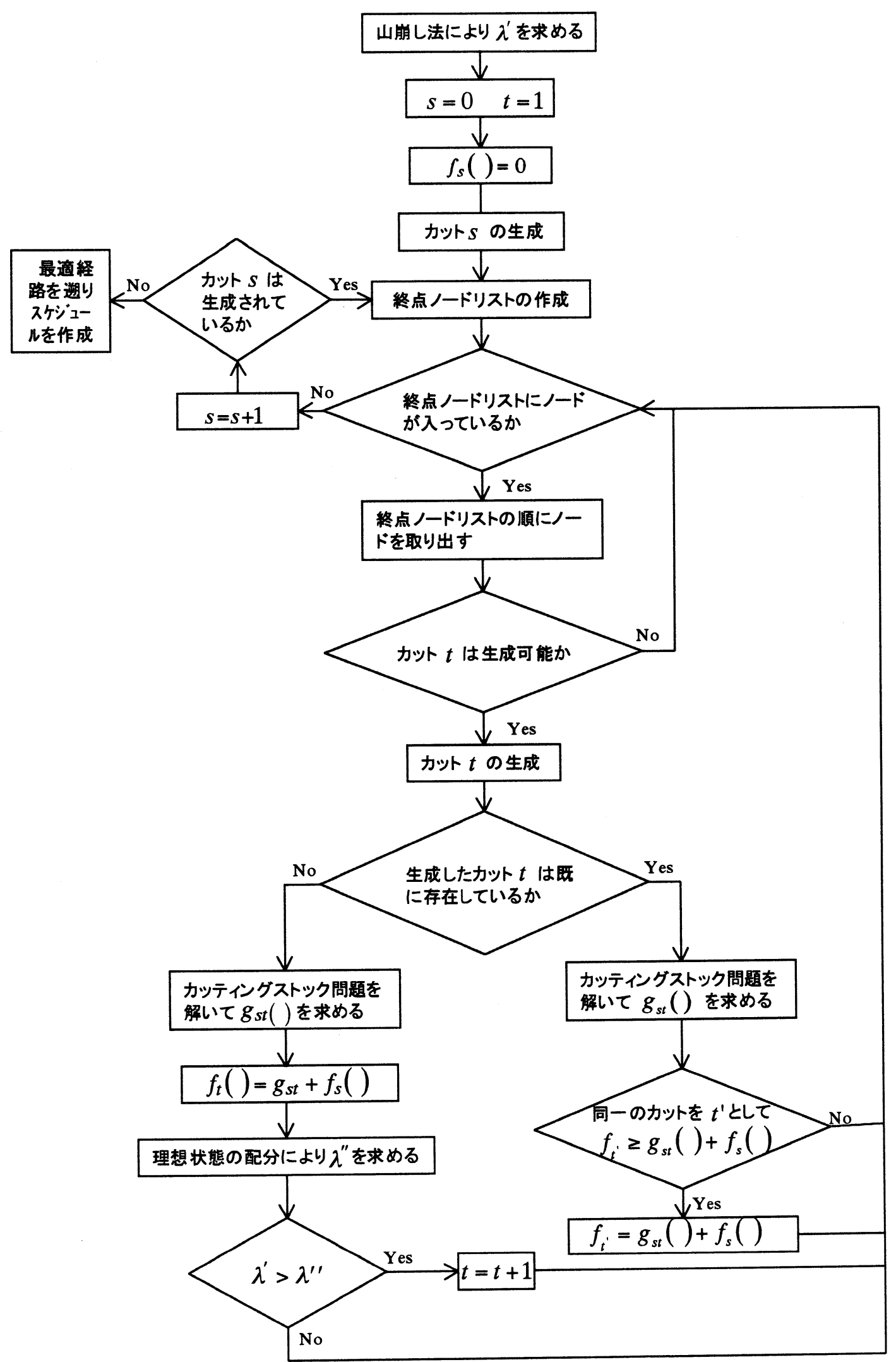

図ー6新たな解法アルゴリズム 


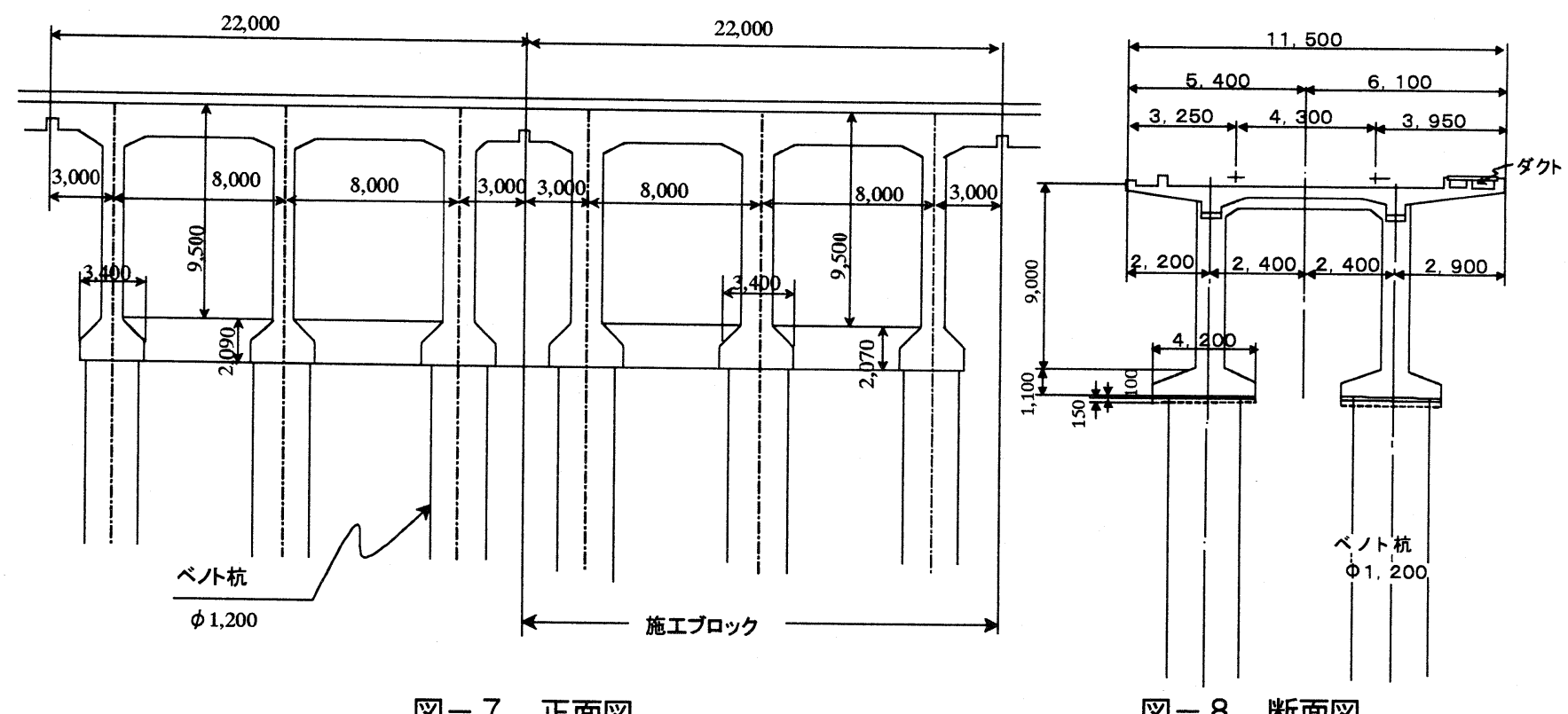

図-7 正面図

図一 8 断面図

ットワークのノードvをすべて抽出

し、ノード番号の小さい順に終点

ノードリストへ取れる。

ステップ2 . 終点ノードリストの順番にノードを 取り出す。このノードvについて $C_{i}^{s}=0$ かつ $\delta_{v i}=-1$

となる作業 $i$ の存在を調べる。もし、 存在していれば次のノードを取り 出し同様の処理を行う。

もし、存在していなければ、ステ ップ3へ。

ステップ 3 ．もし、 $C_{i}^{s}=0$ かつ $\delta_{v i}=+1$ ならば $C_{i}^{t}=1$ 、

もし、 $C_{i}^{s}=1$ かつ $\delta_{v i}=-1$ ならば $C_{i}^{t}=0$ 、

それ以外ならば

$C_{i}^{s}=C_{i}^{t}$

として新たなカットベクトルを作 成する。

ステップ 4 . 終点ノードリストにまでノードが残 っていれば $t=t+1$ としてステップ 2 へ。

終点ノードリストにノードがなけ れば、終了する。

以上のような処理を解法アルゴリズムの中に 導入することにより、必要なカットのみを生成 しながらの DP 手法適用による効率的なカットネ ットワークの最適経路探索が可能となる。なお、
これらの処理を追加した PERT/MANPOWER 問題の 最適解を求めるための新たな解法アルゴリズム を図ー6にフローチャートとして示しておく。

\section{4. 大規模工程ネットワークでの適用計算}

ここでは、実際レベルの高架工事の例を用いて、 開発した PERT/MANPOWER 問題の解法アルゴ リズムによる適用計算を行った。さて、ここで取 り上げる高架工事の対象となる構造物の正面図お よび断面図を示すと図ー7、図ー8のようである。 図に示されているように、構造物はべノト杭基礎 を有し、18スパンからなる鉄筋コンクリート構 造様式が採用されているものとしている。施工に あたっては、施工効率の観点からの検討の結果、 連続する 3 スパンを 1 施エブロックとして計画し たものとしているので、プロジェクトは結果とし て 6 の施工ブロックを含むこととなる。また、各 施工ブロックは基礎 $\rightarrow$ ベース $\rightarrow$ 柱 $\rightarrow$ スブ $\rightarrow$ ダク トといった各構造物部位の施工順序に従う形で作 成された図ー9に示すようなすべて同じ作業を含 む工程によって建設されるものとする。

施工計画は、これらの6つのブロックを建設し ていくために必要な図ー9に対応する 186 の単 位作業と、これらの単位作業に先行する準備作業 ならびにすべての単位作業に後続する跡片付け作 業によって構成されている。作業計画作成の結果、 各作業の所要時間、要員数、使用機械台数が求め られ、表ー 1 に示すような作業特性值を得られた 

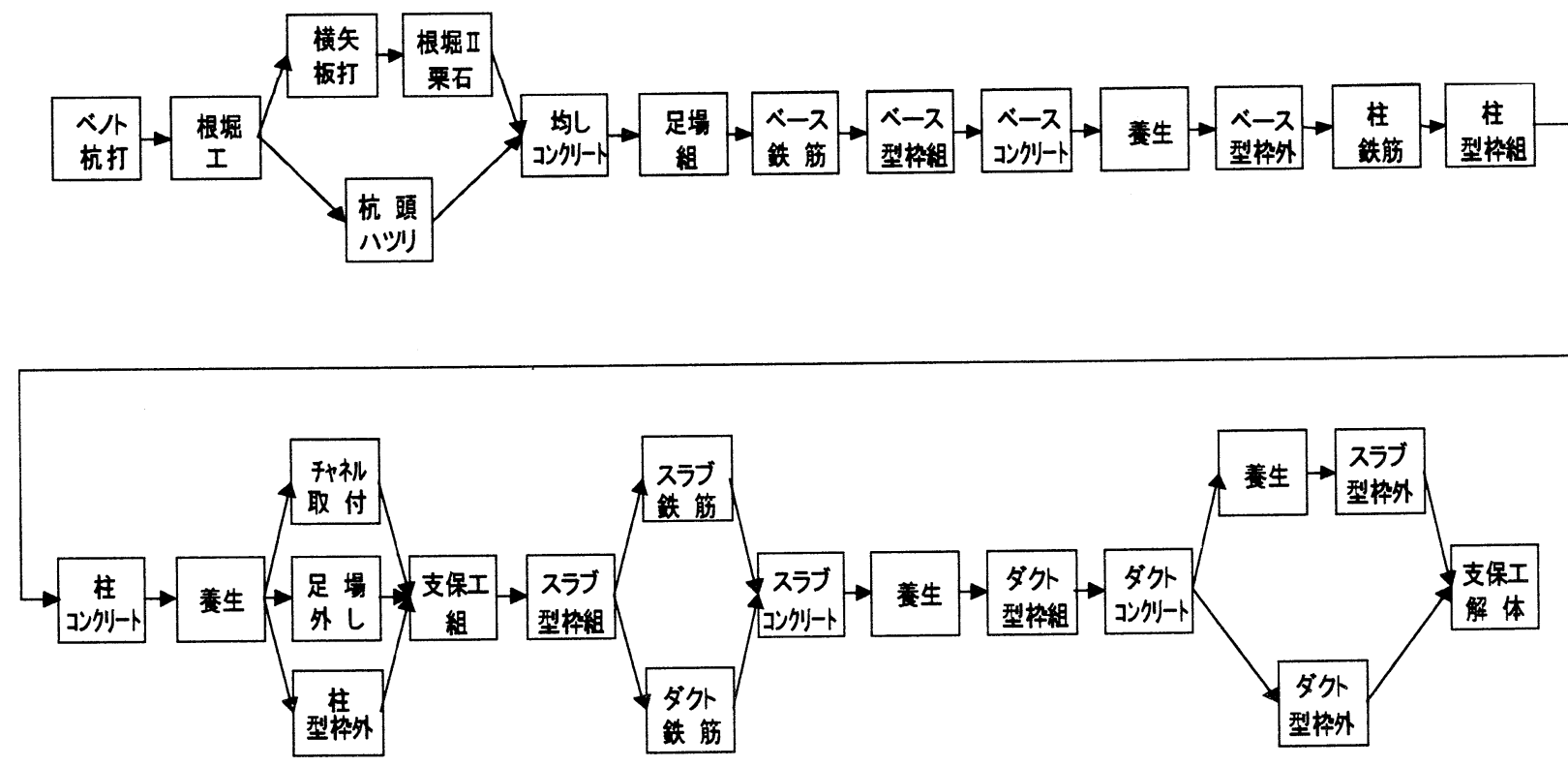

図ー9 各施エブロックの作業工程

ものとする。なお、この作業特性値は多大な量となっており、紙面の関係上すべてを揭載すること は割愛し、表一 1 にはその一部 表-1 作業特性値

\begin{tabular}{|c|c|c|c|c|c|c|c|c|c|}
\hline 作業番号 & 所要時間 & 要 & & & & & 巣 & & 根 \\
\hline & & I & 鉄筋 工士 & II & 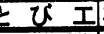 & 根罢權 & 杭打槽 & 罗はつり機 & 以レーン \\
\hline $\begin{array}{l}1 \\
2\end{array}$ & 15(日) & 5 (人) & $0($ 人) & $5(\lambda)$ & 0 (人) & 0(台) & 0 (台) & 0 (台) & 0 (台) \\
\hline $\begin{array}{l}2 \\
3\end{array}$ & & & 0 & 3 & 2 & 0 & 1 & 0 & \\
\hline $\begin{array}{l}3 \\
4\end{array}$ & 4 & 0 & 0 & 0 & 0 & 1 & 0 & 0 & 0 \\
\hline $\begin{array}{l}4 \\
5\end{array}$ & 2 & 0 & 0 & 2 & 0 & 0 & $\begin{array}{l}0 \\
0\end{array}$ & 0 & 0 \\
\hline $\begin{array}{l}5 \\
6\end{array}$ & 1 & $\begin{array}{l}0 \\
0\end{array}$ & $\begin{array}{l}0 \\
0\end{array}$ & ${ }^{6}$ & $\begin{array}{l}0 \\
0\end{array}$ & 0 & 0 & 1 & $\begin{array}{l}0 \\
0\end{array}$ \\
\hline 7 & 1 & 4 & 0 & 4 & 0 & 0 & 0 & 0 & 0 \\
\hline 8 & 3 & 0 & 0 & 0 & 4 & 0 & 0 & 0 & 0 \\
\hline 9 & 3 & 0 & 6 & 0 & 0 & 0 & 0 & 0 & 0 \\
\hline 10 & 2 & 5 & 0 & 0 & 0 & 0 & 0 & 0 & 0 \\
\hline 11 & 1 & 0 & 0 & 7 & 0 & 0 & 0 & 0 & 0 \\
\hline 12 & 2 & 0 & 0 & 0 & 0 & 0 & 0 & 0 & 0 \\
\hline 13 & 1 & 5 & 0 & 0 & 0 & 0 & 0 & 0 & 0 \\
\hline 14 & 1 & 0 & 2 & 0 & 0 & 0 & 0 & 0 & 0 \\
\hline 15 & 2 & 6 & 0 & 0 & 0 & 0 & 0 & 0 & 0 \\
\hline 16 & 1 & 0 & 0 & 6 & 0 & 0 & 0 & 0 & 0 \\
\hline 17 & 4 & 0 & 0 & 0 & 0 & 0 & 0 & 0 & 0 \\
\hline 18 & 1 & 6 & 0 & 0 & 0 & 0 & 0 & 0 & 0 \\
\hline 19 & 1 & 0 & 0 & 2 & 1 & 0 & 0 & 0 & 0 \\
\hline 20 & 2 & 0 & 0 & 0 & 3 & 0 & 0 & 0 & 0 \\
\hline 21 & 4 & 0 & 0 & 0 & 5 & 0 & 0 & 0 & 1 \\
\hline 22 & 6 & 5 & 0 & 0 & 0 & 0 & 0 & 0 & 1 \\
\hline 23 & 6 & 0 & 5 & 0 & 0 & 0 & 0 & 0 & 1 \\
\hline 24 & 1 & 0 & 5 & 0 & 0 & 0 & 0 & 0 & 1 \\
\hline 25 & 1 & 0 & 0 & 8 & 0 & 0 & 0 & 0 & 1 \\
\hline 26 & 7 & 0 & 0 & 2 & 0 & 0 & 0 & 0 & 1 \\
\hline 27 & 2 & 4 & 0 & 0 & 0 & 0 & 0 & 0 & 1 \\
\hline 28 & 1 & 0 & 0 & 6 & 0 & 0 & 0 & 0 & 1 \\
\hline 29 & 3 & 0 & 0 & 0 & 0 & 0 & 0 & 0 & 1 \\
\hline 30 & 1 & 4 & 0 & 0 & 0 & 0 & 0 & 0 & 1 \\
\hline 31 & 3 & 5 & 0 & 0 & 0 & 0 & 0 & 0 & 1 \\
\hline 32 & 4 & 0 & 0 & 0 & 4 & 0 & 0 & 0 & 1 \\
\hline 33 & 3 & 0 & 0 & 3 & 2 & 0 & 1 & 0 & 0 \\
\hline 34 & 4 & 0 & 0 & 0 & 0 & 1 & 0 & 0 & 0 \\
\hline 35 & 2 & 0 & 0 & 2 & 0 & 0 & 0 & 0 & 0 \\
\hline 36 & 1 & 0 & 0 & 6 & 0 & 0 & 0 & 0 & 0 \\
\hline 37 & 2 & 0 & 0 & 2 & 0 & 0 & 0 & 1 & 0 \\
\hline 38 & 1 & 4 & 0 & 4 & 0 & 0 & 0 & 0 & 0 \\
\hline 39 & 3 & 0 & 0 & 0 & 4 & 0 & 0 & 0 & 0 \\
\hline 40 & 3 & 0 & 6 & 0 & 0 & 0 & 0 & 0 & 0 \\
\hline 41 & 2 & 5 & 0 & 0 & 0 & 0 & 0 & 0 & 0 \\
\hline 42 & 1 & 0 & 0 & 7 & 0 & 0 & 0 & 0 & 0 \\
\hline 43 & 2 & 0 & 0 & 0 & 0 & 0 & 0 & 0 & 0 \\
\hline 44 & 1 & 5 & 0 & 0 & 0 & 0 & 0 & 0 & 0 \\
\hline 45 & 1 & 0 & 2 & 0 & 0 & 0 & 0 & 0 & 0 \\
\hline 46 & 2 & 6 & 0 & 0 & 0 & 0 & 0 & 0 & 0 \\
\hline 47 & 1 & 0 & 0 & 6 & 0 & 0 & 0 & 0 & 0 \\
\hline 48 & 4 & 0 & 0 & 0 & 0 & 0 & 0 & 0 & 0 \\
\hline 49 & 1 & 6 & 0 & 0 & 0 & 0 & 0 & 0 & 0 \\
\hline 50 & 1 & 0 & 0 & 2 & 1 & 0 & 0 & 0 & 0 \\
\hline
\end{tabular}
を示しておいた。さらに、以上 のような各作業間の技術的順序 関係をノードを作業とするプロ ジェクトグラフ型の工程ネット ワークで表示したのが図ー10 である。さらに、開発した解法 アルゴリズムをこの例題に適用 するために、プロジェクトグラ フ型の工程ネットワークを、3 0のダミ一作業を追加すること により矢印を作業とするアロー ダイアグラムに変換したものが 図ー11である。なお、表一2 にはこのアローダイアグラムの 接続行列の一部を示した。また、 この例題工事で必要となる表一 1 に示した工事用資源の投入量 に対する資源制約としては、大 工 14 (人)、鉄筋工 18 (人)、土 工 18 (人)、とび工 12 (人)、根 掘機 6(台)、杭打機 6(台)、はつ り機 4(台)、クレーン 5(台)であ るものとして数值演算を行った。 以上のような適用計算の結果、 最小工期 121(日)が算出された。 また、求められた最適スケジュ 一ルを各工事用資源の山積み図 

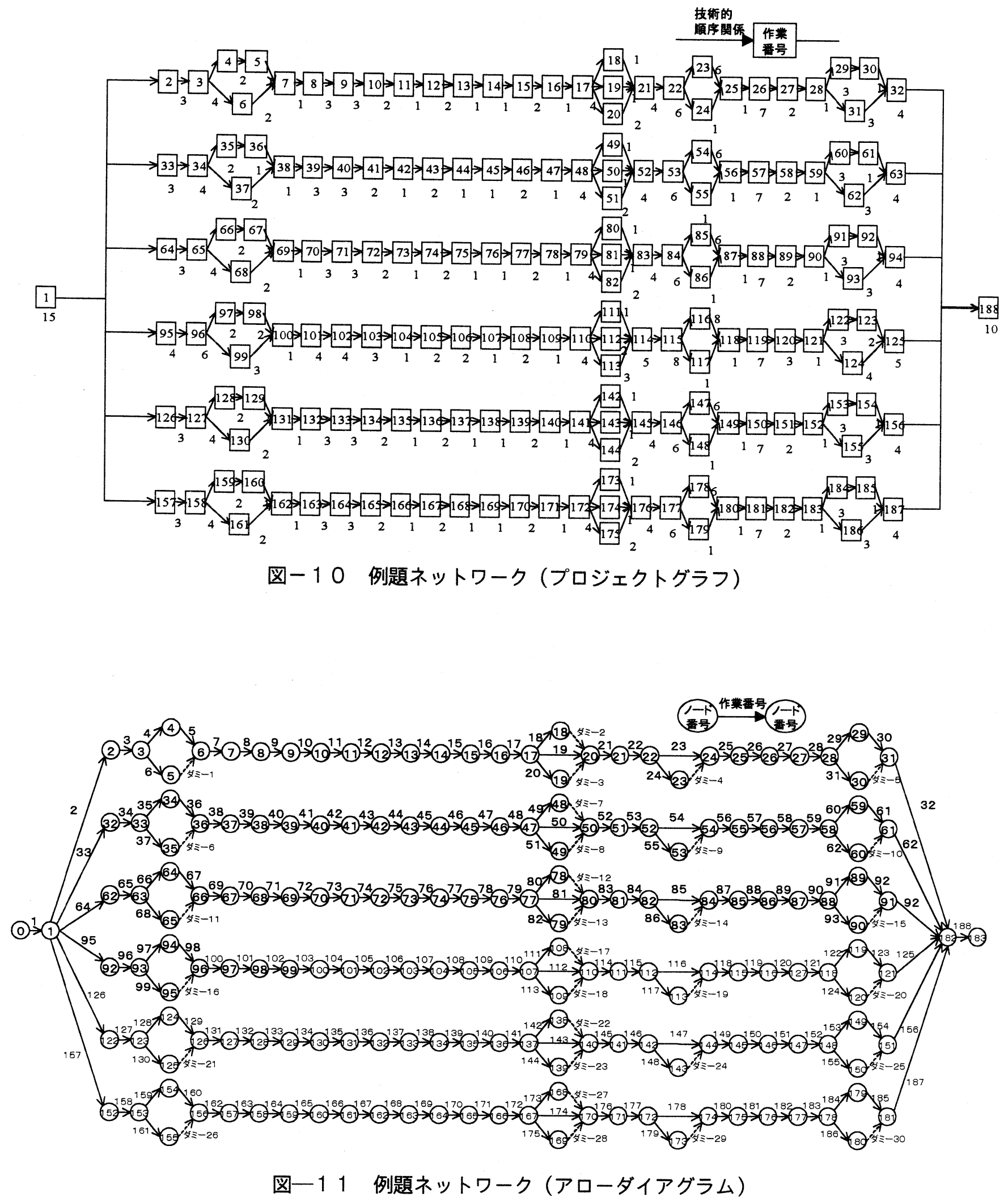
表-2 接続行列（一部）

\section{作莱番号 $\rightarrow$}

\begin{tabular}{|c|c|c|c|c|c|c|c|c|c|c|c|c|c|c|c|}
\hline & \% & $2 \%$ & 3 & 46 & 3 & 6 & $1 / \%$ & 8 & $1 \%$ & 10 & / 11 & 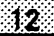 & 13 & /4 & 16 \\
\hline 0 & +1 & 0 & 0 & 0 & 0 & 0 & 0 & 0 & 0 & 0 & 0 & 0 & 0 & 0 & 0 \\
\hline 箦 & -1 & +1 & 0 & 0 & 0 & 0 & 0 & 0 & 0 & 0 & 0 & 0 & 0 & 0 & 0 \\
\hline 2 & 0 & -1 & +1 & 0 & 0 & 0 & 0 & 0 & 0 & 0 & 0 & 0 & 0 & 0 & 0 \\
\hline \% & 0 & 0 & -1 & +1 & 0 & +1 & 0 & 0 & 0 & 0 & 0 & 0 & 0 & 0 & 0 \\
\hline \% & 0 & 0 & 0 & -1 & +1 & 0 & 0 & 0 & 0 & 0 & 0 & 0 & 0 & 0 & 0 \\
\hline 5 & 0 & 0 & 0 & 0 & 0 & 0 & 0 & 0 & 0 & 0 & 0 & 0 & 0 & 0 & 0 \\
\hline 6 & 0 & 0 & 0 & 0 & -1 & -1 & +1 & 0 & 0 & 0 & 0 & 0 & 0 & 0 & 0 \\
\hline 1 & 0 & 0 & 0 & 0 & 0 & 0 & -1 & +1 & 0 & 0 & 0 & 0 & 0 & 0 & 0 \\
\hline 8. & 0 & 0 & 0 & 0 & 0 & 0 & 0 & -1 & +1 & 0 & 0 & 0 & 0 & 0 & 0 \\
\hline 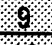 & 0 & 0 & 0 & 0 & 0 & 0 & 0 & 0 & -1 & +1 & 0 & 0 & 0 & 0 & 0 \\
\hline 10 & 0 & 0 & 0 & 0 & 0 & 0 & 0 & 0 & 0 & -1 & +1 & 0 & 0 & 0 & 0 \\
\hline 11 & 0 & 0 & 0 & 0 & 0 & 0 & 0 & 0 & 0 & 0 & -1 & +1 & 0 & 0 & 0 \\
\hline 12 & 0 & 0 & 0 & 0 & 0 & 0 & 0 & 0 & 0 & 0 & 0 & -1 & +1 & 0 & 0 \\
\hline 6 & 0 & 0 & 0 & 0 & 0 & 0 & 0 & 0 & 0 & 0 & 0 & 0 & -1 & +1 & 0 \\
\hline 48 & 0 & 0 & 0 & 0 & 0 & 0 & 0 & 0 & 0 & 0 & 0 & 0 & 0 & -1 & +1 \\
\hline 46 & 0 & 0 & 0 & 0 & 0 & 0 & 0 & 0 & 0 & 0 & 0 & 0 & 0 & 0 & -1 \\
\hline
\end{tabular}

として示したのが図ー12である。なお、今回の 計算時間は、 $\mathrm{C}$ 言語によるプログラムを Pentium II $400 \mathrm{Mz}$ の CPU をもつパソコンを使用した場合 に50 分程度であった。この例題ネットワークの すべてのカットを抽出し、カットネットワークを 作成するのに要した時間が 200 時間を超えるこ とを考えれば、本稿で示したアルゴリズムの変更 により、かなりの程度の操作性の向上が実現して いるといえる。

\section{5. おわりに}

本稿においては、本研究がこれまで進めてきた PERT/MANPOWER 問題を含む工程ネットワーク への工事用資源配分問題の最適解法の開発に関す る研究の過程で得られた理論的成果をべースとし て、実際レベルの大規模工程ネットワークを対象 とした大規模数值演算にも耐え得る効率的な解法 アルゴリズムの開発を行った。そこでは、まず山 崩し法によって算出される妥当解を基準値として、 ブランチ\&バウンド法における下界值と同様の考 え方のもと、それ以降の計算を行うに值しない力 ットネットワークの経路の探索を中止することに より、計算量の削減を罒る方法を提案した。さら に、これまでの研究成果として理論的に保証され ているカットネットワークの存在を前提として、 以上のように変更を加えた DP の計算過程の中で 破棄される経路上の無駄なカットを抽出すること なく必要とするカットのみを逐次生成しながら最
適経路を求める方法を示し、これを解法アルゴリ ズムの中に導入した。

以上のように変更を加えた最適解法を作業の数 が 188 となる大規模な高架工事の工程ネットワー クに適用したところ、大幅な計算時間の短縮が確 認された。

\section{参考文献}

1) 春名攻, 滑川達: PERT/MANPOWER 問題の 最適解法の開発研究一カットネットワーク における最適資源配分問題への変換を用い た新しい解法一, 土木計画学研究・論文集, 1998

2 ) 春名攻, 滑川達, 櫻井義夫 : 工事用資源の 最適投入量用決定問題に関する理論的研究, 建設マネジメント研究・論文集 vol.5, 土木 学会建設マネジメント委員会, 1997

3 ) 春名攻, 滑川達: ネットワーク工程表の構 造特性分析と最適工程計画モデル構築に関 する理論研究, 建設マネジメント研究・論 文集 vol.4, 土木学会建設マネジメント委員 会, 1996

4) 春名攻 : 建設工事に打ける施工計画に関す るシステム論的研究, 京都大学学位論文, 1971 

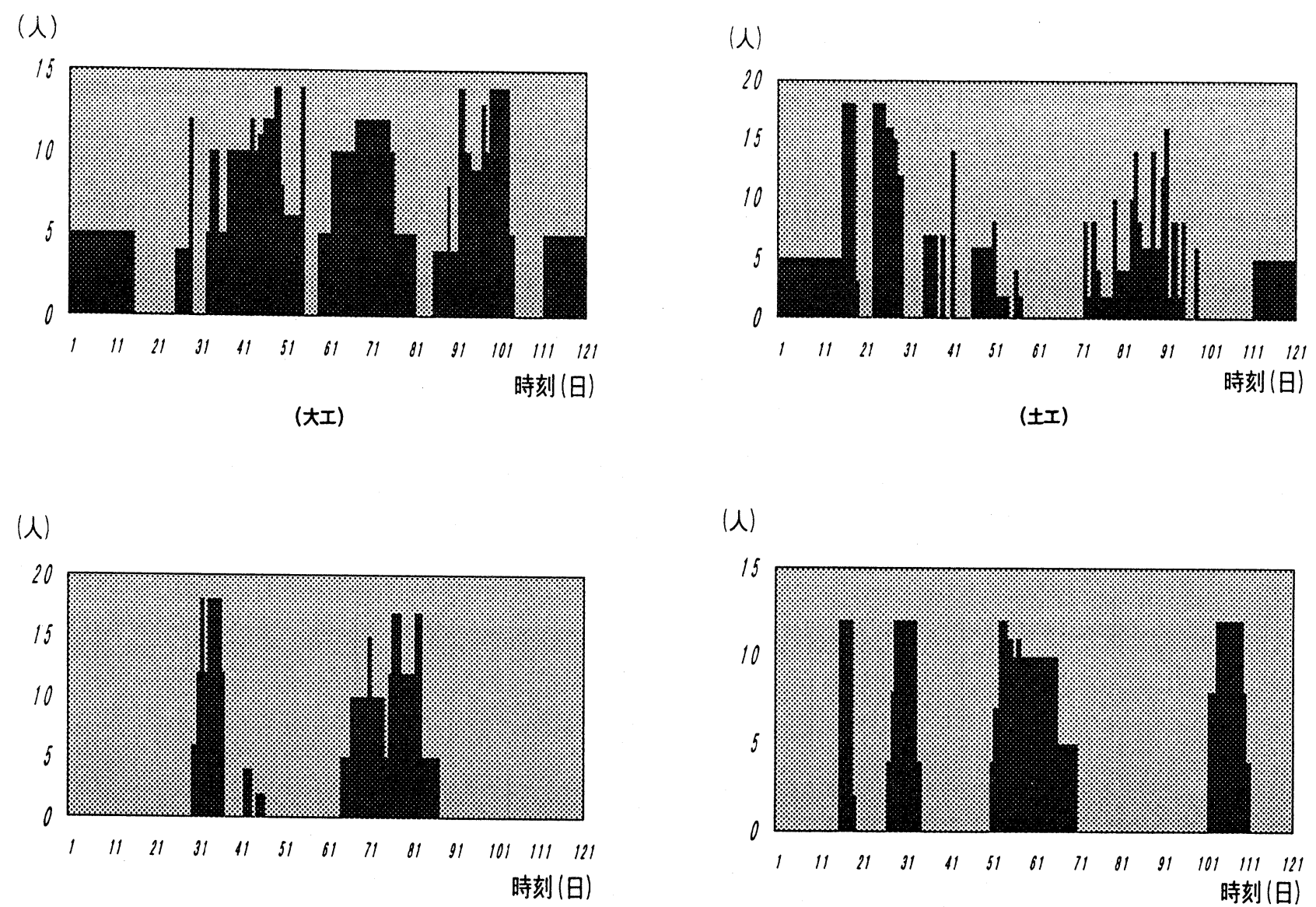

(镇旅工)
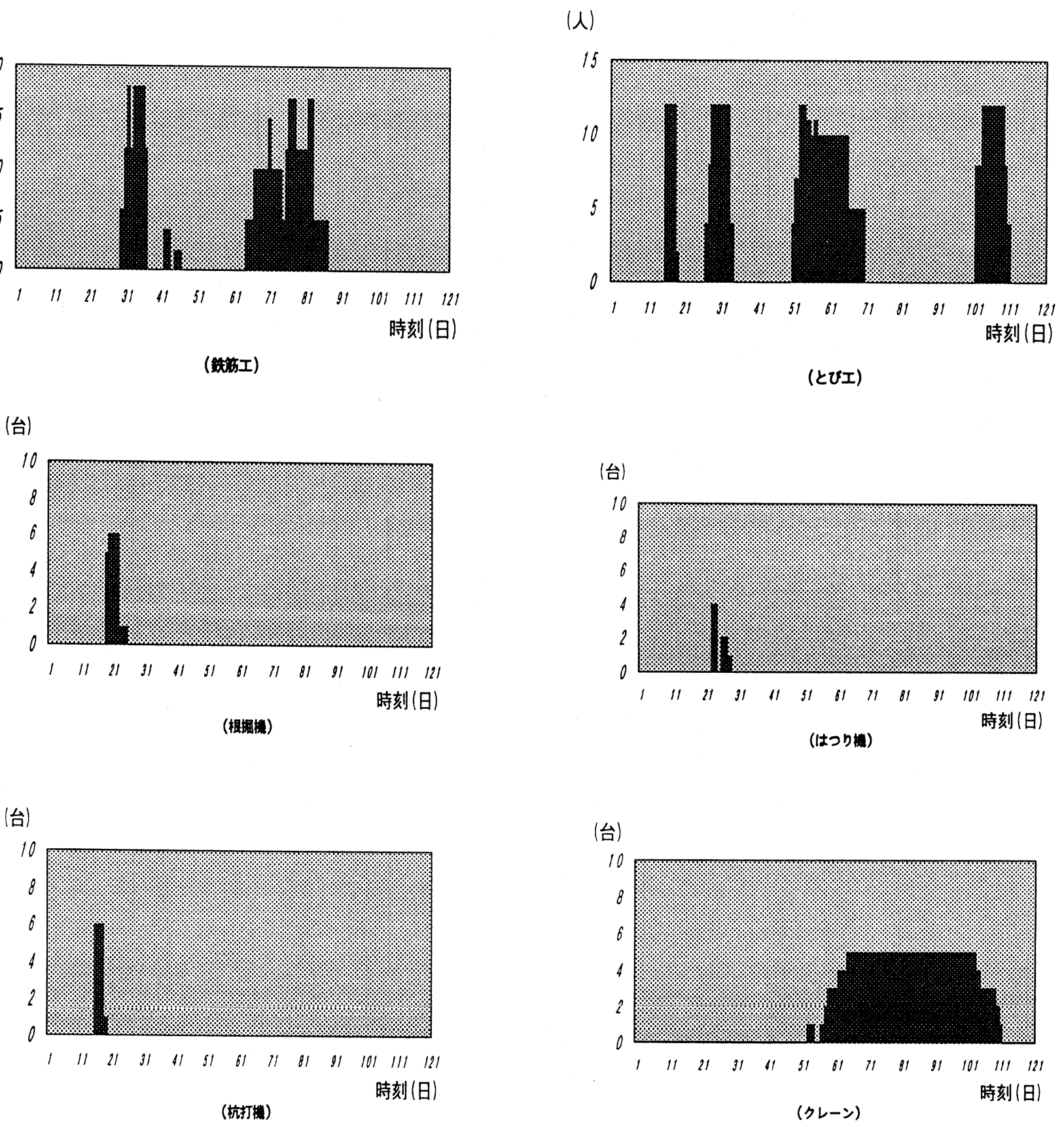

図ー12 最適スケジュールの資源山積み図 


\section{Development of Algorithm for Obtaining Optimal Solution of PERT/MANPOWER Problem Effectively}

In this paper, it is aimed to develop a new algorithm for obtaining optimal solution of PERT/MANPOWER problem effectively. In this study new type model formulation and its algorithm to solve it have been established from the different viewpoint of existing method through the transforming to optimal resource allocation problem on cut-network which is structured based on the analysis of topological characteristics of construction project network. The new algorithm can reduce computational quantity of DP calculation on cut-network based on its theoretical study and lower bound concept of branch $\&$ bound method. 